\title{
The Problems of Implementing Blended Learning Class in Civic Education Students, University of Lampung
}

\author{
Devi Sutrisno Putri*, Muhammad Mona Adha, Berchah Pitoewas \\ Department of Civic Education, Faculty of Teacher Training and Education, University of Lampung, Indonesia
}

Received December 9, 2019; Revised February 10, 2020; Accepted February 25, 2020

Copyright $\odot 2020$ by authors, all rights reserved. Authors agree that this article remains permanently open access under the terms of the Creative Commons Attribution License 4.0 International License

\begin{abstract}
The era of digital revolution always requires every individual to master information and communication technologies in order to optimize human capabilities according to the times. Almost the entire sphere of human life is characterized by technology, including education. Education should be able to provide students with the skills capable to face the prospect of change. Digital-based learning facility is one of the efforts to develop ability to master technology and information in the world of education. The digital-based learning or e-learning that combines conventional learning with non-conventional learning is blended learning. Blended learning system learning is one manifestation of the challenges of the digital revolution era also requires students to have adaptive skills. Learning new blended learning began to be implemented in the Teaching Faculty of Education (Guidance and Counseling) University of Lampung (Unila) in the second semester of academic year 2018-2019. It did not rule out the possibility because there were a lot of problems in implementation. Therefore, the purpose of this study was to find the constraints faced in the implementation of blended learning. It was intended to attempt improvements in the application of blended learning next. This study used a phenomenological qualitative approach. Selection informant research was undertaken by using purposive sampling, which the data obtained from informants in accordance with the needs and goals of the study. The expected results of this study are to be used as material for later evaluation.
\end{abstract}

Keywords Problems, Blended Learning

\section{Introduction}

Education is one aspect that has a fundamental role in shaping the future generation into qualified and responsible generation and able to welcome the progress in the future. Education is also working to develop the ability, character and a dignified civilization because education plays an important role in preparing qualified human resources. The objective of producing quality human resources is also necessary to quality education. The quality of education can be determined from various aspects, some of which are curriculum, educators, facilities and prasaranya, and so forth.

Curriculum development occurs along with the times. The era of the digital revolution requires every individual to master information and communication technologies in order to optimize human capabilities according to the times. To answer these challenges, many things have been pursued by various educational institutions. One way is to create learning innovation. Access to obtain a variety of information is not a difficult thing to do in this digital era. So even in the world of education, learning by using technology and information continue to be developed in order to learn digital literacy to every individual. Blended learning is one of the e-learning system which was implemented in FKIP Unila. Blended learning is a combination between conventional learning with digital media-based learning Atua cyberspace. Learning through blended learning, students can access materials and information that have been uploaded in the website whenever and wherever that has been provided by each lecturer of the course.

Blended learning class in faculty of teacher training and education (FKIP) Unila was implemented in the second semester of this academic year 2018-2019. The entire major in FKIP Unila has been registering some courses to be implemented using blended learning models including civic education (PPKn) majoring. At the beginning, PPKn register four courses implemented using blended learning models. Early adoption of this lecture system will possibly encounter various obstacles. Therefore, research is needed on the constraints in implementing blended learning on student tuition PPKn FKIP Unila. Its aims for improving the implementation is in subsequent semesters. To study 
or research in the case of lectures' problem in implementing blended learning, it should begin from components contained in the learning process. Principal components that determine the enforceability of the lecture system with blended learning models are lecturers, facilities and infrastructures, as well as learning resources. Meanwhile, the supporting component is the role of the chairman of the study program. Thus, in this study the researchers will focus on these components.

\subsection{Literature Review}

\subsubsection{What Is a Blended Learning?}

The term is used to describe blended learning courses that try to combine face-to-face learning with online learning. In addition to blended learning, there is another term that is often used among blended learning and hybrid learning. Terms both contain the same meaning which is a combination, mixing or combination of learning. Williams, Bland, and Christie (2008) describe blended learning as a "combination of traditional face-to-face learning and distributed learning which is an instructional model that allows lecturers, students, and content to be in different locations. Meanwhile, Singh (2003) defines "blended learning as a combination of delivery methods that complement one another and work to support students' learning.

1. combining or mixing of web-based technology to accomplish an educational goal;

2. combining pedagogical approaches (e.g, constructivism, behaviorism, cognitivism) to produce an optimal learning outcomes with or without instructional technology;

3. combining any form of instructional technology with face-to-face instructor-led training;

4. combining instructional technology with actual job tasks.

Blended learning is interpreted as a combination of conventional or traditional learning with electronic or digital-based learning. "Blended learning environments combine traditional and e-learning methods and media. As a consequence, the didactic improvements by the use of adequate mixes according to learning content and learner groups are possible" (Renner, Laumer, and Weitzel, 2014). The learning model of blended learning can be done such as incorporating web-based learning, streaming video, audio synchronous and asynchronous communication with conventional learning "face to face". In the process of implementation of e-learning, it takes a Learning Management System (LMS), which serves to regulate the administration of the organization of learning in e-learning model. LMS is also known as CMS (course management system), generally built web-based CMS, which will run on a web server and can be accessed by participants via a web browser (web client). Servers are usually placed at a university or school or other institutions, which can be accessed from anywhere by participants, by utilizing an internet connection. Thus, the learning is done conventionally. Blended learning is usually done in the classroom which is then combined with online learning and both are conducted independently or in collaboration by means of information and communication technology infrastructure, which can be accessed from anywhere by participants, by utilizing an internet connection. The concept of blended learning is described as follow.

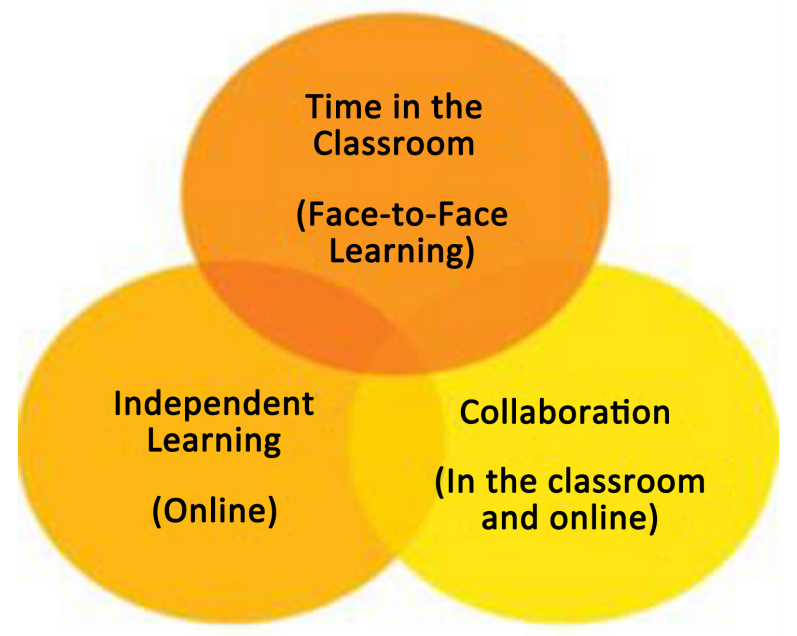

Source:

http://orangecharterschool.org/the-future-of-learning-has-arrived-atocs/

Figure1. The concept of blended learning

Based on a survey conducted by Center for Digital Education in 2012, blended learning has many benefits in assisting the learning process of students. The survey results found 1) offer alternate learning opportunities, $92 \%$. 2) offer distance learning to a board-base number of individuals, $85 \%$. 3) promote more student engagement, $70 \%$. 4) help to increase academic achievement, $61 \%$. 5) help to increase classroom capacity, 59\%. 6) increase student retention, 56\%. 7) decreases cost, 50\%. The technology learning model for blended learning has four major benefits. Because it makes it easier for instructors or faculty / facilitators to reach students at $92 \%$, help instructors to measure how students use digital materials at $73 \%$, scale institution or department efforts at $61 \%$ and help to decrease costs overall at $54 \%$.

The analysis result Moskal, Dziuban, and Hartman (2012), show is that blended learning can be successful if the organizers or in this case the faculty understand the objectives to be achieved. "For an institution to succeed in blended learning it must have a sense of what goals and outcomes it wants to achieve. These goals may be institutional goals, faculty goals, student goals or a combination of all three. Institution-centered goals might include more efficient use of classroom resources, or extending campus outreach "(Moskal, Dziuban, and Hartman, 2012). Referring to the results of the analysis, 
the cooperation between the various parties, such as faculty leaders, team managers, faculty, and students is needed in developing blended learning lesson.

\subsubsection{Lecturer Competence in Blended Learning Class System}

Competence is defined as the knowledge and skills, and basic values are reflected in the habit of thinking and acting. Not only priority of knowledge aspects, but the essence of competence also includes the skills and behaviors that should be owned, controlled, and actualized by individuals in performing the duties of professionalism. This is in line with the opinion (Žeravíková et al., 2015), which states that "competencies are based on activities, not only on the knowledge. They include communication, the development of the ability to learn, social competencies, problem solving, working with ICT, etc".

The competence of lecturers in this study is defined as the ability of lecturers to implement the learning process. Therefore, there are some elements of competence must be owned by a professor. Pedagogical competence, personal competence, professional competence and social competence are the kinds of competencies that must be mastered by a professor. Lecturer plays an important role for the enforceability of learning in higher education, even to education services and quality improvement in higher education. In education the term "the man behind the system" is applied. Man is a key factor that determines the strength of education (Miller, 1980). In fact, as the education services industry is the "front line providers and determines the quality of service delivery system", the lecturer is at the forefront in determining the quality of higher education services (Sallis, 2002). Thus, competent faculty is the goal which should continue to be pursued by the college. Robbins (2000) categorizes skills into four parts, namely: 1) basic literacy skills, 2) technical skills, 3) interpersonal skills, and 4) problem-solving skills. Furthermore (Žeravíková et al., 2015) explains that.

The professional competencies of a lecturer can be characterized as the ability to give lectures influenced by the abilities, knowledge, experience and skills of a person, but also one's willingness and capacity to use one's potential functionally in adult teaching and to bear responsibility for one's decisions during the educational process.

It was also set in the Act No. 14 Year 2005 on Teachers and Lecturers Article 1 Paragraph (10), which states that the competence of teachers and lecturers is a set of knowledge, skills and behaviors that must be owned, lived, ruled, and actualized by a teacher or lecturer in performing the duties of professionalism."Professional teachers must demonstrate these competencies (knowledge, skills, and values) for effective teacher education program completion and effective performance "(Lucky and Yusoff, nd, 2013).

In the Indonesian Government Regulation No. 19,2005 on National Education Standards, the elucidation of Article 28 paragraph (3), there are four dimensions of competence that must be owned by teachers and lecturers, these competencies include:

1. Pedagogic competence, the ability to manage the learning of learners that includes an understanding of the learners, the design and implementation of learning, evaluation of learning outcomes, and the development of students to actualize their potential.

2. Personal competence such as the ability of teachers or lecturers' personality like steady, stable, mature, disciplined, wise noble and authoritative, and becoming role models for students,

3. Professional competence such us the ability of mastering learning materials widely and deeply.

4. Social competence such us the ability of teachers or lecturers being a part of the community to communicate and interact effectively with students, fellow teachers, staff, parents or guardians, and surrounding communities.

Yohanita (2011) in his research states that the pedagogic and professional competence of a lecturer have a significant effect on the quality of learning. This is in line with research Eman Sulaiman (2008), in his study says that the professional competence and personality of a lecturer have a significant effect on the quality of student learning. Therefore, Slameto (2010) argues that professional educators (faculty) should be able to create a learning process in such a manner so as to stimulate students to learn actively and dynamicly in meeting the needs and setting goals, and to improve learning outcomes. Any activity of learning required in the conditions and circumstances, includes the conduct of online-based learning.

A lecturer said it is possible to master professional standards of competence and basic competence in the subject, develop learning materials, master the material, structure, concepts, and scientific mindset. Lecturers must equip themselves with mastery learning theory and principles of learning that educates. Lecturers are compulsory to share their own science to students. Professional lecturers should be able to work independently or in groups, have the work ethic, confidence, and have a high responsibility as an agent of learning.

Professional lecturers who are professors have the skills to educate and are able to apply for educational success by mobilizing all the capabilities, effort and responsibility for the success of education. The principle of "do what is best for the education" inspires activities. Professionalism requires some competencies of teachers, which are that 1 ) they have the academic knowledge to be able to give to the students' academic ability. 2) they have knowledge of the values to be able to consistently apply the noble values to students. 3) they have knowledge of psychology in order to know the character and psychological problems 
of learners. 4) they have extra knowledge related to nature as humans who do the learning throughout life. Lecturers must develop and improve their quality continuously in order to build a better image. As an educator, lecturer must always follow the development of science and technology, especially in the era of industrial revolution 4.0 requires all lines of digital-based life.

\subsubsection{Learning Resources in the Blended Learning Class System}

Learning resources are useful for the effectiveness of learning activities in the achievement of learning goals, including 1) providing a learning experience directly and concretely to the students, 2) presenting something impossible to be held and visited, 3) adding and memerluas horizon of grain in the class , 4) providing accurate and up to date, 5) helping solve education problems both within the micro and macro, 6) motivating positive, if organized and planned pemnafaatannya appropriately, 7) stimulating to think, act, and grow more kanjut (Ahmad Rohani, 2007).

Learning resources easily accessible in the digital age are coming from online media. "People can learn through virtual schools, universitives, online classes, and free or open educational resources. Learners can build their knowledge by participating in virtual world, online communities, and social media "(Song and Bonk, 2016), Aside from online media, learning resources can also be obtained from a variety of things. Rohani (1997) classifies learning resource as follows: 1) the learning resources in print, such as books, magazines, plans and others, 2) none-printing learning resources, such as films, slides, video, tapes, models, etc. , 3) learning resources in the form of facilities: auditorium, a library, a study room and so on, 4) learning resources in the form of activities: interviews, observation, games and others, 5) learning resources that form the environment of the community, friends, terminal and etc.

Learning resources are factors that support for teachers and students to acquire and develop learning materials. The quality of education is closely related to learning outcomes achieved by every student. Student learning outcomes are influenced by the source of learning, independent learning and learning strategies applied by teachers. Mulyasa, (2011: 177) states that learning resource can be defined as anything that can provide ease of learning, in order to obtain some information, knowledge, experience, and skills required. Referring to the Mulyasa's opinion, what is the source of learning not only are the books supporting subjects or subjects, but also everything that can provide a science.

\subsubsection{Means in the Blended Learning Class System}

Judging from the function or role towards the implementation of learning, then learning tools can be divided into three kinds: yiatu learning tools, props, and the medium of instruction (Daryanto and Farid 2013).
Learning tool is a tool that is used directly in the learning process, such as stationery and practice. Props is a tool in the learning process, in the form of objects that already gives understanding to the students, from the abstract to the concrete. Media teaching is a learning tool that is used as an intermediary in learning, to further improve the effectiveness and efficiency in achieving educational goals.

The characteristics and capabilities of each media need to be considered by the lecturers so that they can choose the right media in accordance with the conditions and needs. In addition, careful selection of media in learning is very dependent on the experience and knowledge of lecturers of media, ranging from simple media to the sophisticated media. Media that can be used in learning dikalsifikasikan as follows: 1) the media are not projected, 2) the projected media, 3) audio media, 4) video media, and 5) computer-based media (Person, 2010).

The lecture system of blended learning models would have to be supported by the personal computer (PC) to be able to access a variety of information that has been uploaded on the page lecturers provided. In addition to access to information, the use of a $\mathrm{PC}$ is also made to discuss online, either with faculty and fellow students. Thus, adequate means of learning which will support the teaching and learning process are effective.

The learning process can be optimized by several elements, one of which is an element of the existing facilities and infrastructure in schools. Facilities and infrastructures become benchmarks of quality of school. Facilities and infrastructure are necessary to support the skills of learners to be ready to compete against the development of science and technology, especially in the era of the 21 st century that emphasizes each individual to become global citizens with superior competencies. Thus, every educational institution should strive to improve the facilities and infrastructure in accordance with the needs of the times.

\section{Materials and Methods}

This study used a qualitative approach. The aim of research with qualitative approach was to understand the situation, events, roles, groups, or certain social interaction.

The researcher seeks to establish the meaning of a phenomenon from the views of participants. This means identifying a culture-sharing group and studying how it develops shared patterns of behavior over time (i.e, ethnography). One of the key elements of collecting the data in this way is to observe your participants' behaviors during their engagement in activities. (Creswell, 2013)

The qualitative research can be defined as the process of investigation in which researchers gradually make sense of a social phenomenon to distinguish, compare, 
duplicate, mengatalogkan, and classify objects peneltian. The study involved researchers to explore the setting of investigators so that researchers entered the world through continuous interaction, searching for meaning and perspective informants.

Based on the characteristics of the subject and the focus of the research, the design of the study employed a phenomenological research design. Phenomenological qualitative approach was chosen because the purpose of this study was to examine in detail the social phenomena that occur in a real and candid world. In this approach, the researchers sought to find the phenomena and the events that were based on an understanding of the subject's own observer perspective and related to theoretical issues. The use of the phenomenological approach was intended to reveal a phenomenon that appears as the object of research, which is to analyze problems in implementation of blended learning models in a lecture held in PPKn FKIP Unila.

Phenomenological research design was chosen in order to to find the variables that exist in the real context regarding statements of what, how, and why on:

a. The competence of lecturers in applying the model of blended learning in the lecture including preparation of learning tools, implementation of learning, and conducting the assessment.

b. A learning tool in the implementation of blended learning models. These facilities include the availability and feasibility of instructional media, utilization or use of instructional media, and the lecture hall.

c. Learning resources in the implementation of blended learning models.

d. The role of chairman of the courses in the application of blended learning models.

\subsection{Location}

The research location which was chosen was in Prodi PPKn FKIP Unila PPKn considering that Prodi was one of the courses that are conducting lectures blended learning system in the second semester of academic year 2018-2019.

\subsection{Participant}

In qualitative research, the term refers to the informant samples, the person who is the source of information. Research with qualitative approach requires the presence of researchers in the field, because the researchers act as an instrument of research as well as data collectors. Therefore, this study was conducted with the depth interviews with key informants who can provide answers consistent with the fact that actually happened. Selection informant research was done by using purposive sampling, that the data obtained from informants in accordance with the needs and goals of the research, through this technique was obtained from key informants, and from key informants further to other informants with snowball technique (snowball sampling). Furthermore, in qualitative research a well-known term analisisi unit is the unit of analysis used in research. In this study, the data analysis unit was FKIP Unila PPKn student who attended the lectures with blended learning, faculty PPKn FKIP Unila that applied the blended learning in the lecture, and the chairman of the study program PPKn FKIP Unila.

\subsection{Data Collection Technique}

In this study, the basic techniques in data collection were interviews. Interviews were used as data collection techniques, such as asking a number of questions orally (in depth enterview) to students, faculty, and the chairman of the study program. Interviews were used in this study were semi-structured interviews. While supporters of the techniques were the observation or observation and documentation. Documentation implemented was the result of observation and interview. Data collection activities were obtained from interviews, observations, and the documentations based on the guidelines that had been developed based on the aspect that had been observed which was operationally based on the indicators.

\section{Findings}

\subsection{Identify Problems in the Blended Learning Implementation}

Blended learning was implemented for a semester, the second semester of 2018-2019 in FKIP Unila. That year was the first year FKIP Unila use e-learning to the type of blended leraningedusmart applications and uses. Learning is a blended learning mix between learning face to face with non-face-to-face learning (online). Quantities for its online learning are maximum of 8 meetings and a minimum of four meetings, then the learning is said to be blended learning. The use of blended learning teaching is still limited to the number of courses that can be registered for each program of study, as many as four courses to still study program. Thus, A few new subjects were enrolled to serve for blended learning. It is inevitable that in the implementation of blended learning, there are still many obstacles or problems, given the new prime learning run. The research focus on problems in learning through a blended learning model "3M", man, material, and method.

\subsection{Man}

The first $3 \mathrm{M}$ is the "man", which means its human resources or in this case a lecturer. Problems or obstacles in the blended learning first are the human resources or preformance or are lecturers. There are problems in terms 
of generation gap. Professors who teach in universities not only from one generation, but from different generations. There were no junior seniors, the senior said this is because it has already started approaching the age of the end phase. This relates to the IT skills of the senior lecturer. Lecturers with senior said age is more likely to feel difficult in operating the technology, or commonly referred to as "clueless". Thus, in the implementation of blended learning also will find it difficult. Although it has been taught about the operating procedures of blended learning, senior lecturers are still difficult to operate with a reason to forget when it is not accompanied by more in operating the blended learning. Research conducted by Becker and Jokivirta (2007), Also found that the low reported academics worldwide enthusiasm for using technology in learning. More recently, a large-scale study (over 4,500 teachers) by Allen et al. (2012) found that $65 \%$ of faculty were more afraid of teaching with technology than they were excited by the prospect. Factors that cause this happens are inadequate support and training, time for developing online materials, fears of failure, and beliefs about the value of technology in education.

Meanwhile, from junior professors to lecturers, the ability to operate the technology is not an issue or can be. Junior lecturers have been "digitally literate", so it will not have difficulties in implementing the blended learning. However, the constraints are in terms of motivation. Junior lecturers are less than optimal in utilizing the blended learning. Reasons expressed by some of the junior faculty among others are that the network is unstable, sometimes difficult to be able to access the system of edusmarts, so often overlooked and they do not have time / no time to upload learning materials in the system. Thus, the blended learning was not used and only limited register only during training. From the research, Data obtained as many as 149 users in the category of lecturers FKIP Unila already implementing blended learning. The total number of users of blended learning are 2996 consisting of professors, students, and managers of blended learning system. There are still many lecturers who have not used the blended learning at the beginning of the lecturer haing registered his courses to blended leraning. This has been a problem in the field of human resources in terms of teaching. The trend in the use of blended learning every month for one semester has decreased. At the beginning of the early semester, lecturers registered courses in the "edusmart" application system to be included in blended learning. However, in the following months the number of active users using blended learning decreased, lecturers were only active at the beginning of registration. Here is a graph of the results of data analysis regarding the number of active users of blended learning in the even semester 2018-2019 each month in FKIP Unila.

Furthermore, in the competence of lecturer in blended learning class, show that lecturers who teach have been able to master the concept of material taught. However, because the learning is done using blended learning, the lecturers had difficulty in conveying the material through online media. This is because the professor has not teralu understood how to use the media. Thus, lecturers still have to do face-to-face learning with the students so that the students understand the material being taught and the blended learning have not been fully implemented. Of the four PPKn lecturers who registered their courses for blended learning, only one lecturer was active in their implementation. While the other three lecturers still use blended learning but not optimally use the existing programs in the edusmart application. The number of blended learning users found in FKIP Unila is given on the figure below.

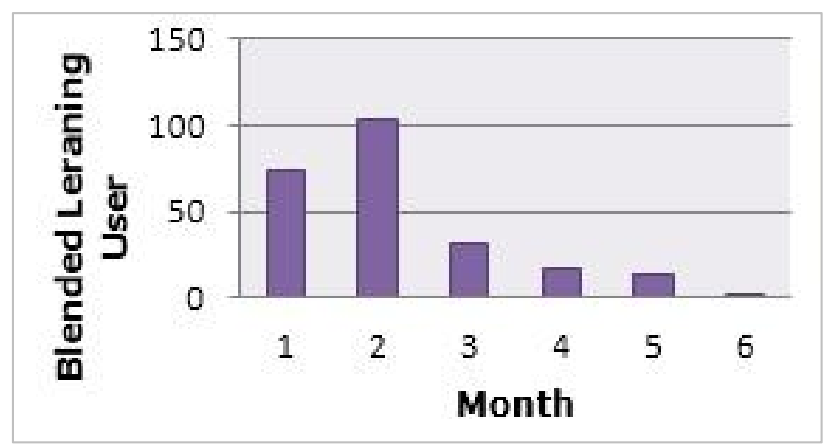

Figure 2. Blended Learning User in FKIP Unila

If viewed from the learning resources in leraning blended learning, what is a source of learning in blended learning is learning lecturer of the course itself, journals, and videos related to the subject matter. In the e-learning system is used, the lecturers to omit some links to journals and videos as well as material that has been prepared in power point slides, so that students are required to study it. Thus, some lecturers PPKn FKIP Unila that uses blended learning lesson has been providing learning resources in order to support the course. However, students still need to actively explore in finding other learning resources that also support the lecture.

In the field of human resources problems are found in students. Students still have the motivation that is lacking in using blended learning lesson. Students find difficulty in accessing edusmart system in order to follow the blended learning. Unstable internet network is also a trigger for the students to follow the blended learning. Thus, many students have registered for the course. The view of the results of the analysis was carried out by the Guzer and Caner (2014), "blended learning is perceived as useful, enjoyable, supportive, flexible and motivator for learners". Blended learning is fun and flexible learning. That is, the survey respondents gave a positive response to the blended learning. However, in this study, it lacks motovasi students to learn to use the online application. This could be because students' understanding of the use 
of blended learning learning applications is still very lacking, so kebermanfaatannya not felt.

\subsection{Material}

The next problem is in terms of "material". Material in this case refers to the infrastructure used in the learning process of blended learning. Edusmart application management team revealed several problems related to the blended learning among others;

1) Limited server capabilities. Limited server capabilities resulted in the difficulties in getting access to the data on the application system. Thus, this makes teachers and students reluctant to optimally use blended learning lesson.

2) The Internet has not been evenly distributed. As mentioned previously, because the blended learning is an online-based learning, the Internet network is needed. Without the Internet, online learning will not happen. Internet network contained in FKIP Unila not evenly distributed to all the lectures in FKIP Unila building. There are still some lecture building which is not covered by the Internet network, such as building D, J building 2nd floor, building G 2nd floor, building $\mathrm{F}$, and other buildings. Of course it makes blended learning inhibited if the student wants to do the blended learning Unila FKIP.
3) Lack of access to speed Internet network. In addition to the Internet network to be uneven FKIP, accessing speed limitations also affect students' learning activities that use blended learning. Internet network connection is not stable or tends to slow, making the blended learning is not running optimally. Students should be able to understand the course materials and do his duties in time of 100 minutes ( 2 credits), but because of limited speed internet access, materials and tasks in the lecture could not be completed.

4) Lack of application used for learning to blended learning. Blended learning using edusmart application assistance in the run. Edusmart applications were managed by FKIP Unila, so this application specifically reserved FKIP Unila. Business edusmart says that until today, edusmart application is still under development, so there are many things that must be associated with a system optimized to the application. When compared with the virtual class, the e-learning applications owned by the University of Lampung, the display of edusmart is still less neat and not optimal. Here is the front page display of virtual class and edusmart.

The display of virtual class and Edusmart in University of Lampung to be combined in blended learning as the home look can be seen on figure 3 and 4 below.
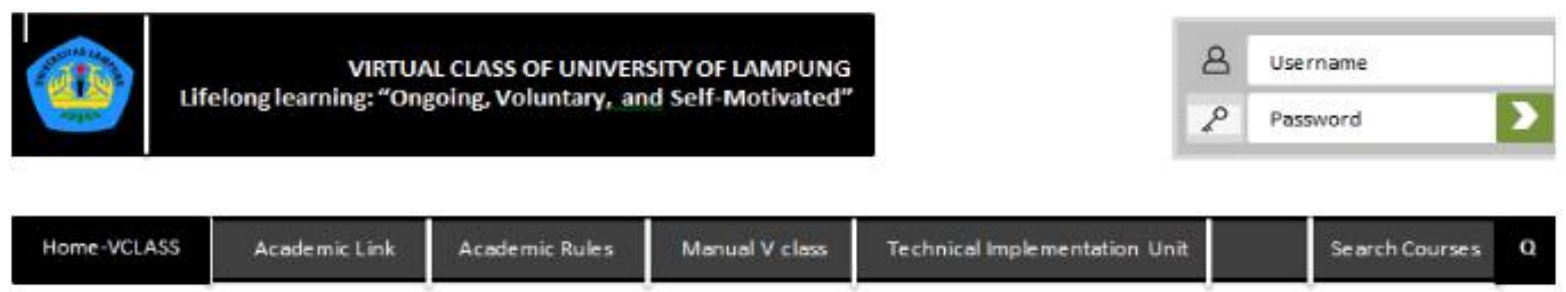

Technical Implementation Unit

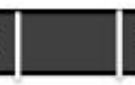

Search Courses $\mathbf{Q}$

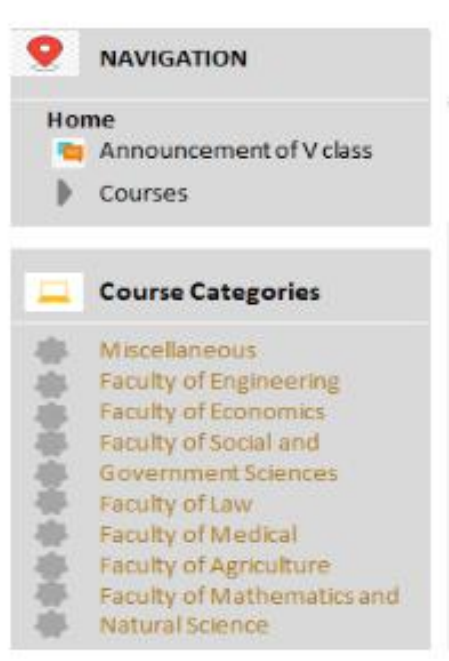

\section{Announcement of Vclass}

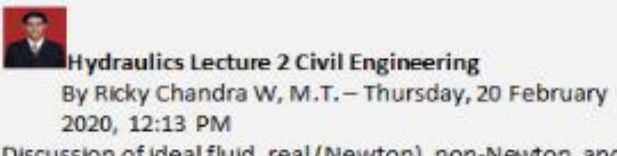

Discussion of ideal fluid, real (Newton), non-Newton, and plastic fluid Real fluid has viscosity, surface tension, and shear tension, so that the flow has more complex equations than the ideal fluid.

Please visit the fluid mechanics class and you can download the material that has been uploaded.

\section{Discuss this topic (0 replies so far)}

Notified to the Lecturer,
Students of University of
Lampung, to access the Virtual
Class service please use the
SSO account (Single Sign On), if
your SSO account has a
problem (forget the
password), please come to the
UPTICT Building 1st floor
service section every working
day.
Emait: tik@kpa.unila.ac.id
Web
https://helpdesktik.unila.acid/
Thanks.

Figure 3. Home Look of Virtual Class of University of Lampung 

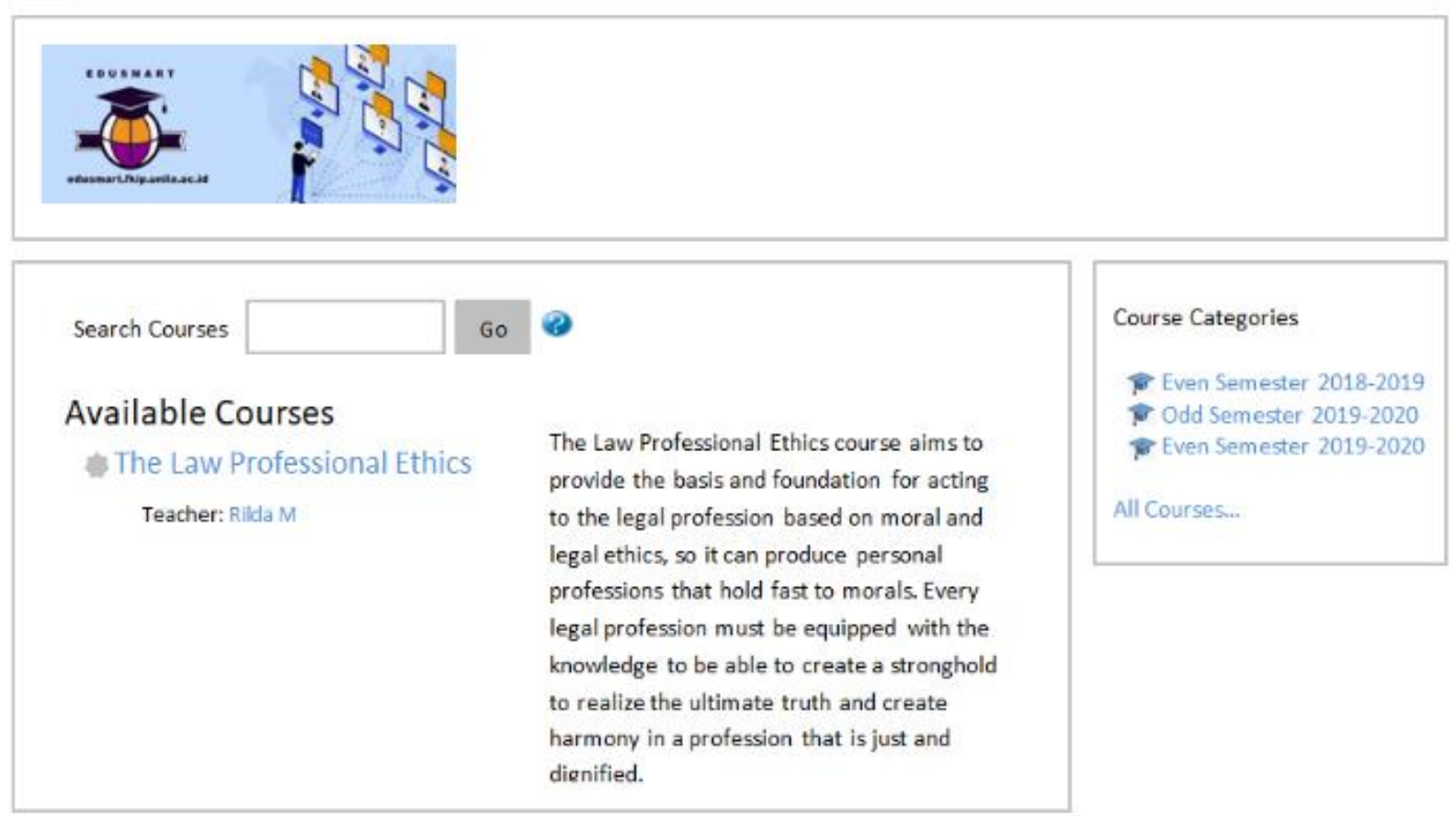

Figure 4. Home Look of Edusmart of FKIP University of Lampung

Thus, Unila not have the facilities and infrastructure that supports the learning model of blended learning. Facilities and infrastructure are not fully able to be used to the maximum. As his case wifi connection faculty have not reached the maximum to all of the existing buildings. One example is in D5 building FKIP Unila where the internet network connectivity is still not good or even totally unable to connect to internet networks faculty. Free access was also an obstacle in the operation of the system for the blended learning. In addition, the private providers that are used are also not functioning optimally, so it is of course difficult for students and teachers to access the Internet in order to operate the blended learning on campus.

\subsection{Method}

The next analysis problem of blended learning implementation is the "method". Method in this analysis is the implementation of blended learning. The application system used in the blended learning in FKIP Unila is "edusmart". To do the blended learning in FKIP Unila, faculty and students should use edusmart application as a medium of blended learning. Team of edusmart application system for blended learning reveals that other obstacles perceived by users apliaksiedusmart are a process that is still fairly complicated registration. This resulted in users or faculty and students finding it difficult to carry out the registration process because they have to go through several steps to be able to join in blended learning. So were the students., They have to wait for confirmation of approval from the faculty that administer join courses with blended learning lesson. Thus, teachers should work again to confirm consent to join the class of teaching. In addition, the management team of blended learning has not provided the full tutorial for faculty and students to operate edusmart blended learning.

\section{Conclusions}

The success of a program is not only supported by one hand, but also supported by various parties in the implementation. Blended learning was not confined to a particular faculty, so that lecturers should be fully responsible for the implementation, and the learning program requires many parties involved. Faculty, team managers, faculty, and students must work together in developing a blended learning lesson. The competence of lecturers, facilities, learning resources, student motivation are important components in the successful use of blended learning. With the cooperation among the various parties, the purpose of learning the implementation of blended learning to the challenges of the era of the industrial revolution 4.0 can be achieved optimally. Blended learning is one solution to the challenging era of the industrial revolution 4.0. "Digital Literacy" is a competence that must be mastered by every individual in this era. The use of technology in blended learning will make the learning more effective. Blended learning's flexibility permits individual institutions and collaborative groups to tailor the concept to maximize its potential 
while being responsive to a new generation of students."Plus, blended learning is another way of engaging of participants in learning and being able to connect to broader communities as they continue their professional development training" (Hilliard, 2015). "And as others have pointed out, the key to a successful blended learning design is the thoughtful integration of classroom face-to-face learning experiences with online learning experiences "(Jeffrey, Milne and Suddaby, 2014). The results of the identification of problems in the implementation of blended learning are learned to be a reference in the revamping of the next program execution. Thus, the implementation of blended learning can run optimally in accordance with the objectives to be achieved.

\section{Acknowledgments}

The researcher is very grateful to the LPPM DIPA BLU University of Lampung for supporting the research funding.

\section{REFERENCES}

[1] Ahmad Rohani. 2007. Educational Instructional Media. Jakarta: Reneka Reserved.

[2] Allen, IE, Seaman, J., Lederman, D., \& Jaschik, S. (2012). Conflicted: Faculty and online education, 2012. Babson Park, MA: Inside Higher Ed and Babson Survey Research Group.

[3] Becker, R., \& Jokivirta, L. (2007). Online learning in universities: Selected Data from the 2006 Observatory report. London: Observatory on Borderless Higher Education (OBHE).

[4] Daryanto \& Farid Mohamad. 2013. The basic concept of management education in schools. Yogyakarta: Gava Media.

[5] Center for Digital Education. 2012. Realizing the full potential of blended learning.

[6] Creswell J W. 2013. Research design: qualitative, quantitative, and mixed methods approaches. United Kingdom: SAGE Publications Ltd.

[7] Güzera B and canera H. The past, present and future of blended learning: an in depth analysis of the literature. Procedia - Social and Behavioral Sciences, Vol. 116, 4596-4603.

[8] Hilliard T. 2015. A Global blended learning practices for teaching and learning, leadership and professional development. Journal of International Education Research-Third Quarte, Vol. 11.

[9] Jeffrey LM, J Milne, and Suddaby G.,2014. Blended learning: How teachers balance the blend of online and classroom components. Journal of Information Technology
Education: Research, Vol. 13, 121-140.

[10] Lucky, EO-I., Yusoff, NBM, nd, 2013. A Conceptual Framework On Teaching Qualifications, Characteristics, Competence and Lecturer Performance for Higher Education Institutions in Nigeria, Vol. 1, Issue 3, E-ISSN No: 2289-4489.

[11] Moskal P, Dziuban C and Hartman, J. 2013. Blended learning: A dangerous idea? Florida. Internet and Higher Education 18, 15-23.

[12] Oliver M and Trigwell K. 2005. Can "blended learning" Be Redeemed? E-Learning, 2 (1), 17-26. Doi: 10.2304 / elea.2005.2.1.17.

[13] Renner D, Laumer S, and T. Weitzel, 2014. Effectiveness and Efficiency of Blended Learning - A Literature Review. IS in Education, IS Curriculum, Education and Teaching Cases (SIGED). Twentieth Americas Conference on Information Systems, Savannah, 2014.

[14] Robbins S P. 2003. Organizational Behavior: New Jersey. Printice Hall, Incupper Saddle River.

[15] E. Sallis, 2002. Total Quality Management in Education, London: Kogan Page Limited.

[16] Singh H. (2003). Building effective blended learning programs. Educational Technology, 43 (6), 51-54.

[17] Song D and Bonk C J. 2016. Motivational factors in informal learning, self-directed online learning resources from. Cogent Educ. 3.https://doi.org/10.1080/2331186X.2016.1205838

[18] Law Number 14 Year 2005 on Teachers and Lecturers, the State Gazette of the Republic of Indonesia Year 2005 Number 157.

[19] Williams NA, Bland W, and Christie G. 2008. Improving student achievement and satisfaction by Adopting a blended learning approach to inorganic chemistry. Chemistry Education Research and Practice, 9 (1), 43-50. Doi: 10.1039 / B801290N.

[20] Žeravíková, I., Tirpáková, A., Markechová, D., 2015. The analysis of professional competencies of a lecturer in adult education. Springer Plus 4. https://doi.org/10.1186/s40064-015-1014-7. 